$$
\begin{aligned}
& (200) \\
& 76 . \mathrm{cm} \\
& -10.849
\end{aligned}
$$

TEM-849

PHOTOGEOLOGIC MAP, VIRGIN SW: QUADRANGLE, WASHINGTON COUNTY, UTAH

C. H. Marshall

May 17, 1955 


\section{Sibarasizy $c_{y}$}

(200)

T67resan UNITED STATES

DEPARTMENT OF THE INTERIOR

GEOLOGICAL SURVEY

WASHINGTON 25, D.C.

IN REPLY REFER TO:

AEC-987/5

Bม⿵冂 178955

$M r$. Robert $D$. Nininger

Assistant Director

Division of Raw Materials.

U. S. Atomic Energy Commission

Washington 25, D. C。

Dear Bob:

Transmitted herewith are two copies of TEM-849, "Photogeologic map, Virgin SW quadrangle, Washington County, Uțah," by C. H. Marshall. This map of part of the Colorado Plateau area is one of the series of $7 \frac{1}{2}$-minute photogeologic quadrangle maps that are being prepared. We are asking Mr. Hosted to approve our plan to publish this map in the Miscellaneous Geologic Investigations series.

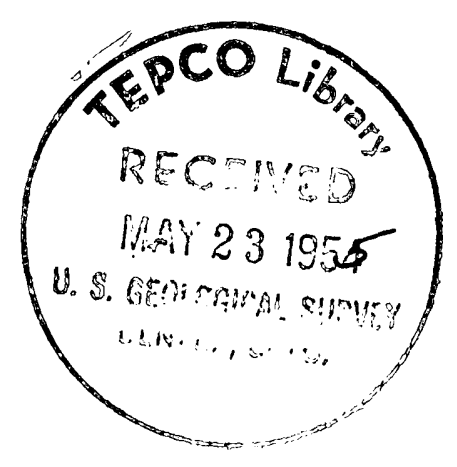

$$
\text { Sincerely yours, }
$$
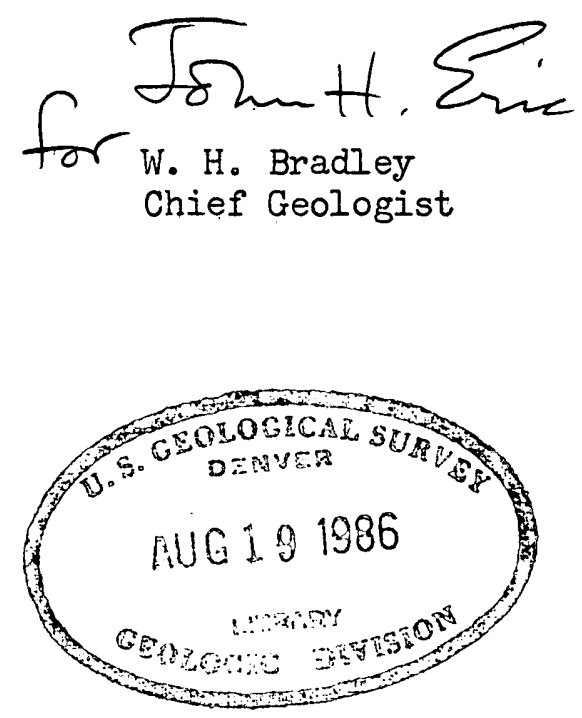
INDEX MAP OF PART OF

THE COLORADO PLATEAU AREA,

SHOWING LOCATION OF

PHOTOGEOLOGIC QUADRANGLE MAPS

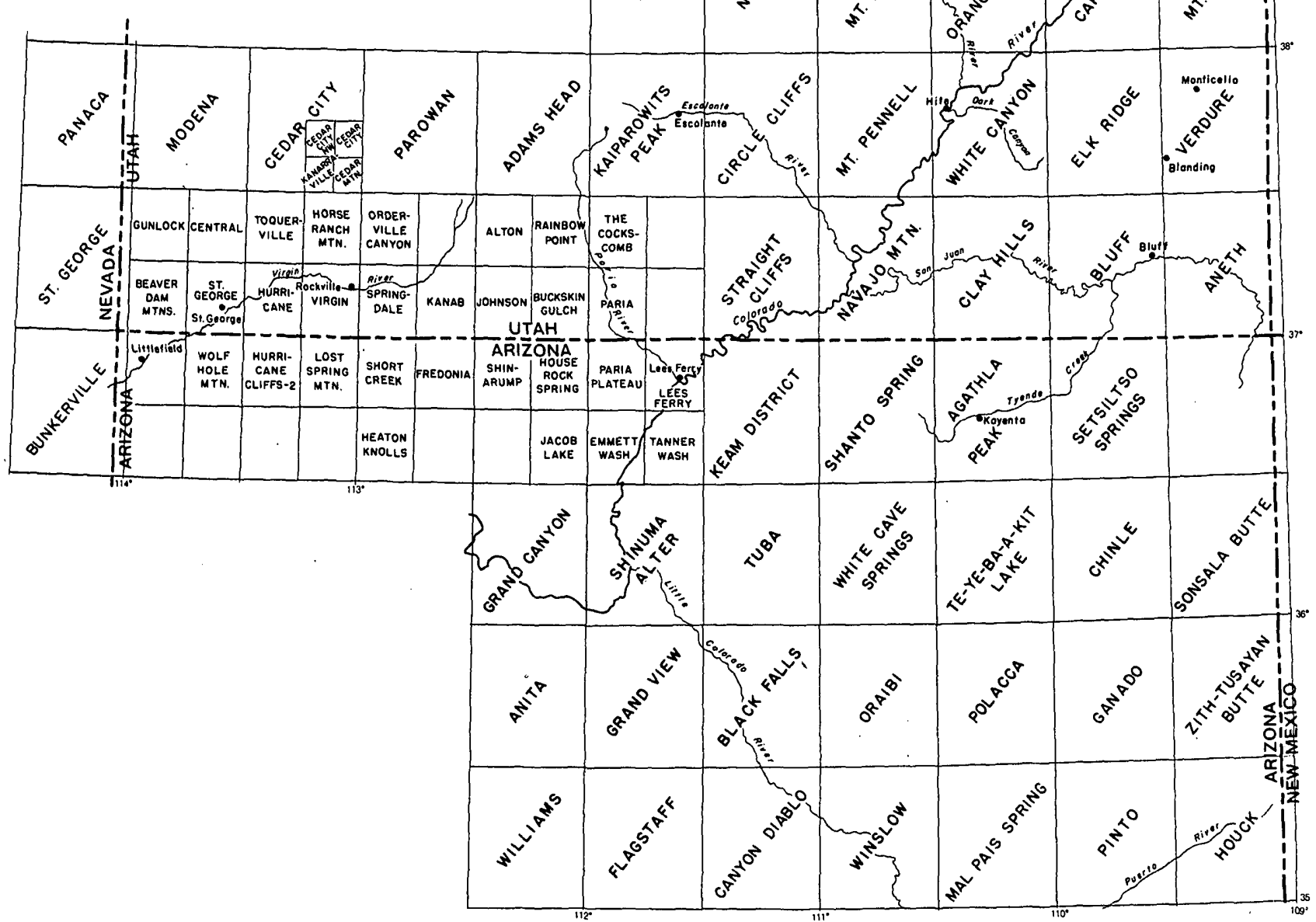

